\title{
THE MALACOFAUNA OF THE UPPER HOLOCENE LACUSTRINE SEDIMENTS OF WIGRY LAKE (N POLAND)
}

\author{
Witold PAWEŁ AlEXANDROWICZ
}

\begin{abstract}
Chair of Stratigraphy and Regional Geology, Academy of Mining and Metallurgy, Mickiewicza 30, 30-059 Kraków, Poland
\end{abstract}

\begin{abstract}
Lacustrine sediments of the lakes Wigry and Białe Wigierskie (Wigry National Park), up to ca. 2.5 $\mathrm{m}$ thick, are developed as lacustrine chalk intercalated with sand, mud and locally overlayed by peat. They contain rich mollusc assemblages comprising taxa typical of lakes and other permanent water bodies. Shallow water and flowing water species are accessory components of the fauna; land snails are represented by single specimens. Dreissena polymorpha (Pallas) and Potamopyrgus antipodarum (Gray), found in upper parts of the profiles, indicate a recent age of the sediments. Lacustrine chalk and calcareous gyttia are typical deposits of the Late Glacial and Early Holocene; in the Upper Holocene they developed only in very few lake basins, and the studied lakes are exceptional. The lithological and malacological analysis of their deposits makes it possible to reconstruct sedimentary processes controlling the accumulation of lake-filling calcareous deposits that are widespeared in N Poland.
\end{abstract}

KEY WORDS: lake deposits, lacustrine chalk, mollusc assemblages, Wigry National Park, N Poland

\section{INTRODUCTION}

Calcareous deposits, developed as lacustrine chalk and/or calcareous gyttia, are typical sediments filling lakes and other water bodies. In many localities they were recognised as deposits accumulated mainly during the Late Glacial and Early Holocene. Mollusc assemblages of such sediments were described by BRODNIEWICZ (1979), KRZYMIŃSKA (1987), AlEXANDROWICZ S. W. (1988, 1989, 1991, 1995), AleXANDROWICZ S. W. \& TCHÓRzEWSKA (1981), AlEXANDrowicz S. W. \& NOWARCZYK (1982), AleXANDrowicz W. P. (1999) and many others. The extant malacofauna of the lakes Wigry and Białe Wigierskie was discussed by several authors (POLIŃSKI 1917, 1922, LEWANDOWSKI 1992, KOŁODZIEJCZYK 1994, 1996, BRZEZIŃSKI 1999 and others). However, the fauna contained in their bottom sediments, developed as lacustrine chalk abounding in snail and bivalve shells, has not been previously investigated.

Wigry and Białe Wigierskie are two large lakes located within the Wigry National Park. The material for the lithological and malacological analyses was collected in July and August 1996, during field work supervised by Prof. dr. hab. JACEK RUTKOWSKI, on the permission of the Wigry National Park.

The studied area is situated in north-eastern part of Poland, ca. $30 \mathrm{~km} \mathrm{SE}$ of Suwałki (Fig. 1). The lake Wigry is one of the largest in Poland, with its $21.7 \mathrm{~km}^{2}$ surface area and maximum depth of $73 \mathrm{~m}$. Calcareous sediments accumulate only in its southern and eastern parts. The lake Białe Wigierskie is smaller. Lacustrine chalk accumulates mainly in its middle and western parts.

Four sites of mollusc-bearing deposits from the lake Wigry were studied in detail. Profiles of lacustrine chalk were situated near islands of Ostrów (Wg-I) and Kamień (Wg-III), and in shallows in the middle of the lake (Wg-II) (Fig. 1). The peat bed (Wg-IV) was located in the northern, marginal zone of the Ostrów Island (Fig. 1). Samples from Białe Wigierskie were collected in a gulf in the north-west- 


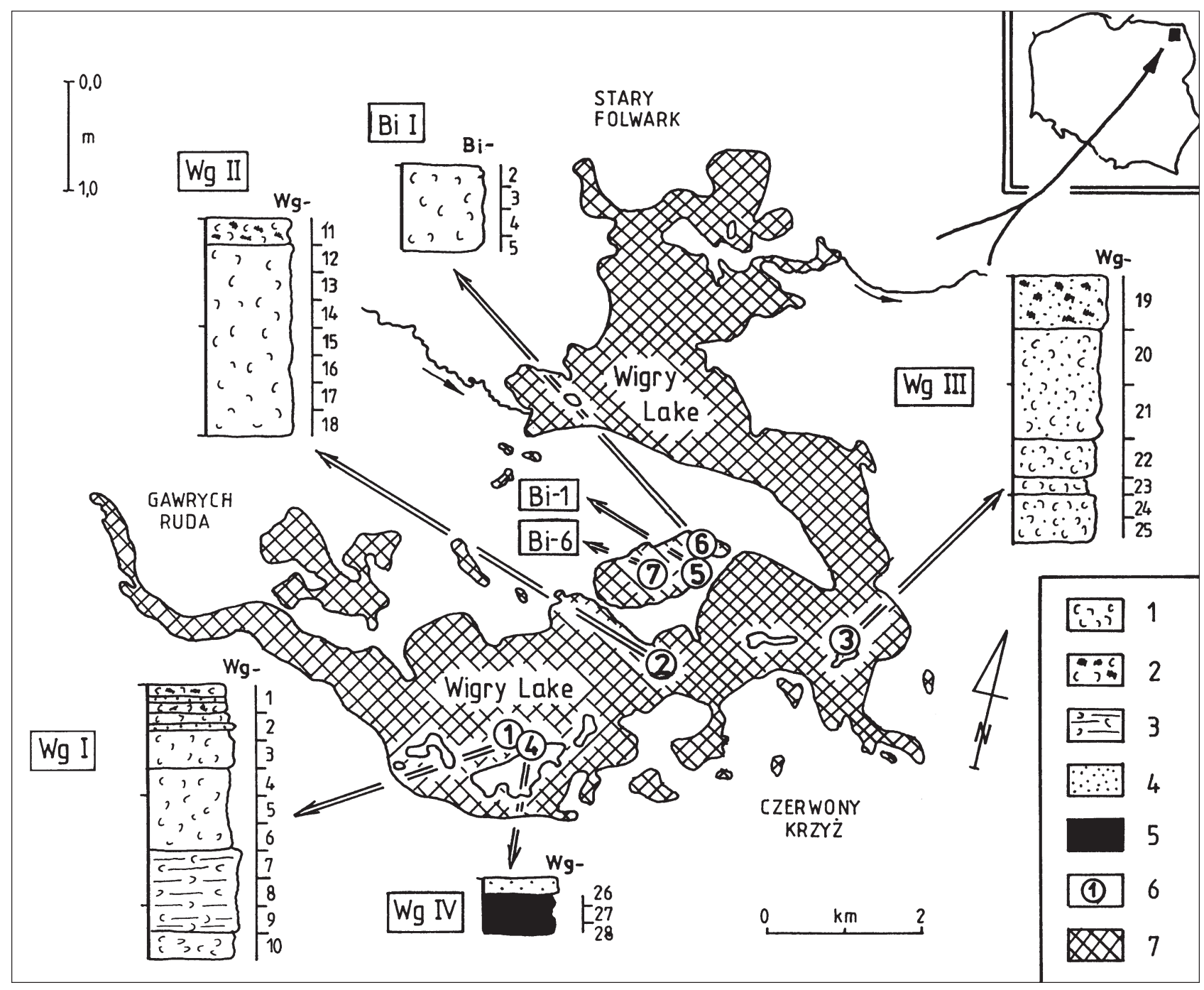

Fig. 1. Profiles and lithology of calcareous deposits in the lakes Wigry and Białe Wigierskie: 1 - lacustrine chalk, 2 - lacustrine chalk with plant remains, 3 - lacustrine chalk with muds, 4 - sand, 5 - peat, 6 - location of the profiles and sampling sites, 7 - lakes

ern part of the lake (sample Bi-1, profile Bi-I) and in a shallow zone of the middle part of the basin (sample Bi-6) (Fig. 1).

The lithology of bottom deposits of the two lakes was recognised based on bore holes (Wg-I, II, III, and $\mathrm{Bi}-\mathrm{I})$ and on single samples (Bi-1, Bi-6). In the lake Wigry the thickness of the calcareous sediments varies between 2.0 (Wg-I and Wg-II) and $2.5 \mathrm{~m}$ (Wg-III) (Figs 1,2). They are developed as white or grey lacustrine chalk with a small admixture of sand and mud. A considerable content of sand was observed only in profile Wg-III. Remains of water plants are common components of these sediments, especially in the upper intervals of the described profiles. The lacustrine chalk is underlied by sand. Twenty-five samples from localities Wg-I, II and III were taken at intervals of 25 cm (Figs 1, 2).

White lacustrine chalk $1 \mathrm{~m}$ thick, without an admixture of sand and mud, occurs in the lake Białe Wigierskie. Four samples from profile Bi-I were collected at intervals of $20 \mathrm{~cm}$. Single samples Bi-1 and $\mathrm{Bi}-6$, as well as three samples from the outcrop of peat and sand (Wg-IV), supplement this material (Figs 1, 2).

\section{MATERIAL AND METHODS}

A total of 34 samples were collected from the localities described above (Wg-1 - Wg-28 and Bi-1 - Bi-6) (Figs 1,2). The sediment was washed, so as to sort out all the mollusc shells and their identifiable fragments. The number of taxa varied between 9 and 34, while the number of specimens was 61-1,276 per sample. 
The whole analysed material contained 54 taxa, including 14 species of terrestrial snails, 26 aquatic snails and 14 bivalves, the total number of specimens being 17,032 . The mollusc fauna found in the profiles of the lake Wigry was richer and more diverse compared to that from Białe Wigierskie.

The ecological grouping applied in this paper follows LOŽEK (1964) and ALEXANDROWICZ S. W. (1987). Four groups: land snails, species of shallow and episodic water bodies, molluscs typical of permanent lakes and taxa preferring moving water have been distinguished in malacological spectra (MSI). Changes in the mollusc communities of particular profiles are il- lustrated in triangular diagrams prepared according to the method described by ALEXANDROWICZ S. W. (1987). Accumulation conditions are expressed by relations between shells and opercula of Bithynia tentaculata (L.) - the so called Bithynia-index (BI) (AleXANDROWICZ S. W. 1987, 1991). The ecological and stratigraphical interpretation has been based on the malacological spectra, triangular diagrams and values of Bithynia-index, as well as the occurrence and habitat requirements of particular species as described by Piechocki (1979) and Piechocki \& DYDUCH-FALNIOWSKA (1993).

\section{RESULTS}

The mollusc fauna of lacustrine chalk from profile Wg-I (samples Wg-1 - Wg-10) is rich and fairly diverse. The number of taxa is 9-18 and the number of specimens ranges from 336 to 879 per sample. The whole material comprises 28 species and 5,464 specimens. The assemblage is dominated by aquatic molluscs, while land snails (Succinea putris (L.)) were found only in the uppermost part of the sequence as a few specimens (Fig. 2, Table 1). Taxa typical of shallow or even episodic water bodies: Valvata cristata Müll., Valvata pulchella Stud., Planorbis planorbis (L.) and some other, are important components of the assemblage (Fig. 2, Table 1). Molluscs inhabiting large lakes (Valvata piscinalis (Müll.), Bithynia tentaculata (L.), Lymnaea peregra ovata (Drap.), Pisidium milium Held, P. crassum Stelfox, P. casertanum (Poli) and others) dominate (Fig. 2, Table 1). Bivalves associated with moving water (Pisidium nitidum Jenyns) are accessory components of the described assemblage. The occurrence of Dreissena polymorpha (Pallas) and Potamopyrgus anipodarum (Gray) in the upper part of the profile is noteworthy (Fig. 2, Table 1). The value of Bithynia-index varies between 0.31 and 0.43 and is typical of the reed-free lake zone (ALEXANDROWICZ S. W. 1987, 1991).

A rich and relatively varied mollusc assemblage was found in lacustrine chalk from profile Wg-II (Wg-11 Wg-18). It comprises 27 mollusc species represented by 7,377 specimens (Fig. 2, Table 1 ). The number of taxa varies from 14 to 20 and that of specimens from 585 to 1,276 per sample. Species typical of shallow water bodies (Valvata cristata Müll., Valvata pulchella Stud.) are common in the whole profile, reaching up to $20 \%$ (Fig. 2, Table 1). Water snails as well as bivalves inhabiting open lakes are the most important components of this assemblage. These are represented by numerous specimens of Bithynia tentaculata (L.), Valvata piscinalis (Müll.), Lymnaea peregra ovata (Drap.), L. peregra ampla (Hartm.), Sphaerium corneum
(L.), Pisidium milium Held., P. casertanum (Poli) and $P$. crassum (Poli) (Fig. 2, Table 1). The mentioned assemblage includes also bivalves inhabiting slowly moving water (Pisidium nitidum Jenyns and P. amnicum (Müll.)). The occurrence of Dreissena polymorpha (Pallas) and Potamopyrgus antipodarum (Grey) in the uppermost part of the profile is noteworthy. The value of Bithynia-index (0.30-0.52) indicates a reed-free part of the lake.

The mollusc assemblage from profile Wg-III (Wg-19 - Wg-25) is quite different. It is composed of 13-34 taxa and 61-514 specimens, depending on the sample (Table 2), including a total of 46 species with 2,033 specimens. Shells of land snails were found in the entire profile. Species of open habitats (Vallonia pulchella (Müll.)) as well as mesophile (Carychium tridentatum (Risso)) and higrophile snails (Carychium minimum Müll., Succinea putris (L.)) were noted. They reach up to $12 \%$ and can be regarded as accessory components of the assemblage (Fig. 2, Table 2). The described assemblage is dominated by aquatic molluscs associated with stagnant, permanent water bodies: Bithynia tentaculata (L.), Lymnaea peregra ovata (Drap.), Pisidium subtruncatum Malm and $P$. casertanum (Poli). Species inhabiting slowly flowing water (Pisidium nitidum Jenyns), as well as snails and bivalves typical of shallow or even temporary water bodies (Valvata cristata (Müll.)) complete this fauna. The occurrence of Dreissena polymorpha (Pallas) and Potamopyrgus antipodarum (Grey) in almost all the samples is a very interesting feature of the profile (Fig. 2, Table 2). The value of Bithynia-index (0.16-0.32) corresponds to the reed-free or partly overgrown zone.

The mollusc assemblage from the peat (profile Wg-IV; samples Wg-26 - Wg-28) is relatively poor but fairly diverse. It comprises 23 species and 615 specimens. The number of taxa varies from 13 to 16, and that of specimens from 132 to 321 per sample. Mol- 


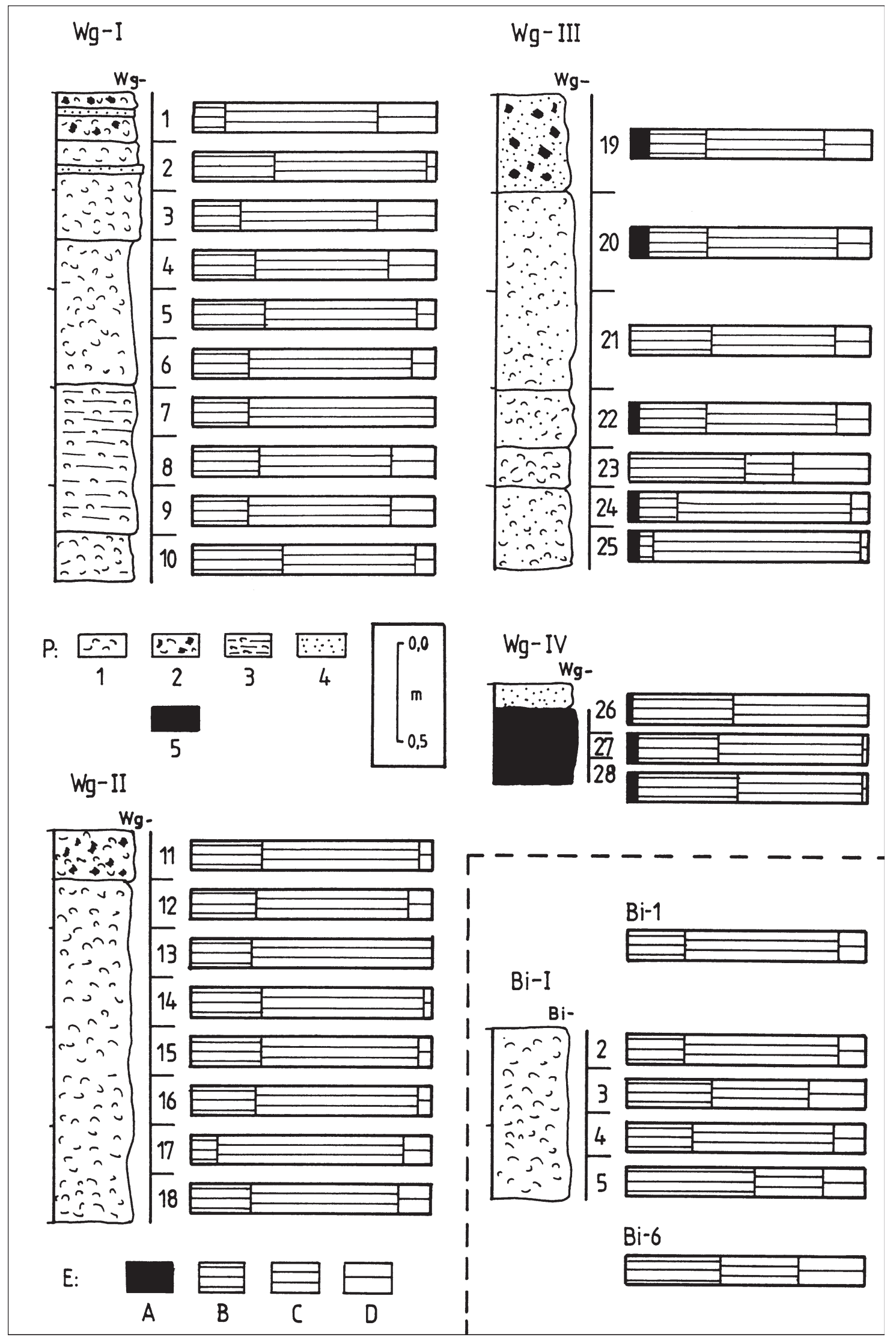

Fig. 2. Malacological composition of the profiles of lacustrine chalk from the lakes Wigry and Białe Wigierskie. P - Lithology of the profiles: 1 - lacustrine chalk, 2 - lacustrine chalk with plant remains, 3 - lacustrine chalk with muds, 4 - sand, 5 peat; E - Ecological composition of malacofauna (according to LO EK 1964 and ALEXANDROWICZ S. W. 1987): A - land snails, B - molluscs typical of shallow water bodies, C - taxa inhabiting large lakes, D - species preferring moving water 
Table 1. Malacofauna of profiles Wg-I and Wg-II. E - Ecological groups of molluscs (according to LO EK 1964 and ALEXANDROWICZ S. W. 1987): 9 - higrophile snails, 10 - molluscs typical of shallow water bodies, 11 - taxa inhabiting large lakes, 12 - species preferring moving water; number of specimens: I - 1-3, II - 4-10, III - 11-32, IV - 33-100, V 101-316, VI - 317-1000 (based on ALEXANDROWICZ S. W. 1987)

\begin{tabular}{|c|c|c|c|c|c|c|c|c|c|c|c|c|c|c|c|c|c|c|c|}
\hline \multirow{2}{*}{$\mathrm{E}$} & \multirow{2}{*}{ TAXON } & \multicolumn{10}{|c|}{ WIGRY LAKE Wg-I } & \multicolumn{8}{|c|}{ WIGRY LAKE Wg-II } \\
\hline & & 1 & 2 & 3 & 4 & 5 & 6 & 7 & 8 & 9 & 10 & 11 & 12 & 13 & 14 & 15 & 16 & 17 & 18 \\
\hline 9 & Succinea putris & I & & & & & & & & & & & & & & & & & \\
\hline 10 & Valvata cristata & III & $\mathrm{V}$ & IV & IV & IV & IV & IV & IV & $\mathrm{V}$ & $\mathrm{V}$ & $\mathrm{V}$ & $\mathrm{V}$ & V & $\mathrm{V}$ & $\mathrm{V}$ & $\mathrm{V}$ & IV & IV \\
\hline 10 & Valvata pulchella & IV & IV & IV & IV & IV & IV & III & IV & II & IV & IV & & & IV & $\mathrm{V}$ & IV & II & IV \\
\hline 10 & Bithynia leachi & & & & & I & & & & II & & & II & & & & & & \\
\hline 10 & Stagnicola palustris & I & & & & & & & & & & & & & & & & & \\
\hline 10 & Planorbis planorbis & I & II & & II & II & III & II & I & II & III & II & III & II & II & II & & & \\
\hline 10 & Musculium lacustre & & & & II & II & & & & & & & & II & IV & & & & II \\
\hline 10 & Pisidium obtusale & & III & & & & & & & & & & & & & & & & \\
\hline 11 & Valvata piscinalis & IV & IV & IV & IV & IV & IV & III & IV & IV & IV & IV & II & & IV & IV & IV & II & IV \\
\hline 11 & $\begin{array}{l}\text { Potamopyrgus } \\
\text { antipodarum }\end{array}$ & II & II & I & & & & & & & & III & I & & & & & & \\
\hline 11 & Bithynia tentaculata & IV & IV & IV & IV & III & IV & IV & III & IV & IV & IV & IV & VI & $\mathrm{V}$ & IV & IV & IV & IV \\
\hline 11 & Physa fontinalis & & & & & & & & & & & & & $\mathrm{I}$ & & & & & I \\
\hline 11 & Lymnaea stagnalis & II & & & & & & & & & & III & II & & & III & III & III & III \\
\hline 11 & $\begin{array}{l}\text { Lymnaea } \\
\text { auricularia }\end{array}$ & & & & & & & & & II & & & & II & II & III & III & III & III \\
\hline 11 & $\begin{array}{l}\text { Lymnaea peregra } \\
\text { ovata }\end{array}$ & IV & IV & IV & IV & IV & IV & IV & IV & $\mathrm{V}$ & IV & $\mathrm{V}$ & $\mathrm{V}$ & V & $\mathrm{V}$ & $\mathrm{V}$ & $\mathrm{V}$ & $\mathrm{V}$ & IV \\
\hline 11 & $\begin{array}{l}\text { Lymnaea peregra } \\
\text { ampla }\end{array}$ & & & & & & & & & III & & III & IV & III & III & IV & III & III & III \\
\hline 11 & $\begin{array}{l}\text { Planorbarius } \\
\text { corneus }\end{array}$ & I & & & & & & & & & & & & & & & & & \\
\hline 11 & Planorbis carinatus & & & & & & & & & & & & II & & & & & & \\
\hline 11 & Anisus vorticulus & & & & & & & & & I & & III & & & & & & & I \\
\hline 11 & Anisus contortus & I & & & & & & & & III & III & III & I & & & & & & \\
\hline 11 & Gyraulus albus & & & & & & & & & & & & & & & & & I & \\
\hline 11 & Armiger crista & & & & & & & & & & & III & IV & IV & III & III & & & \\
\hline 11 & $\begin{array}{l}\text { Hippeutis } \\
\text { complanatus }\end{array}$ & & & & & & & & & & I & & & & & & & & \\
\hline 11 & Sphaerium corneum & & & & & II & II & III & I & III & III & IV & IV & II & III & III & & III & \\
\hline 11 & $\begin{array}{l}\text { Pisidium } \\
\text { henslowanum }\end{array}$ & III & IV & & & III & III & & & I & & & & & & IV & IV & IV & II \\
\hline 11 & Pisidium milium & & & IV & III & IV & IV & III & III & $\mathrm{V}$ & IV & $\mathrm{V}$ & $\mathrm{V}$ & $\mathrm{V}$ & V & IV & III & IV & IV \\
\hline 11 & $\begin{array}{l}\text { Pisidium } \\
\text { subtruncatum }\end{array}$ & & III & & & & & & & & IV & I & II & & & & II & & \\
\hline 11 & $\begin{array}{l}\text { Pisidium } \\
\text { casertanum }\end{array}$ & IV & III & III & III & IV & IV & & & III & III & II & IV & II & & IV & III & IV & III \\
\hline 11 & Pisidium crassum & III & IV & $\mathrm{V}$ & IV & III & III & IV & IV & IV & IV & & III & II & III & IV & IV & IV & III \\
\hline 12 & Pisidium amnicum & & & & & II & II & I & & & & III & III & II & III & III & & III & III \\
\hline 12 & Pisidium nitidum & $\mathrm{V}$ & $\mathrm{V}$ & $\mathrm{V}$ & IV & III & IV & IV & IV & $\mathrm{V}$ & IV & IV & IV & IV & & IV & IV & IV & IV \\
\hline 12 & $\begin{array}{l}\text { Dreissena } \\
\text { polymorpha }\end{array}$ & II & I & I & & & & & & & & II & I & I & & & & & \\
\hline
\end{tabular}


Table 2. Malacofauna of profiles Wg-III, Bi-I and samples Bi-1 and Bi-6. E - Ecological groups of molluscs (according to LO EK 1964 and ALEXANDROWICZ S. W. 1987): 5 - species of open habitats, 7 - mesophile species of moderately humid habitats, 8 - mesophile species of humid habitats, 9 - higrophile snails, 10 - molluscs typical of shallow water bodies, 11 - taxa inhabiting large lakes, 12 - species preferring moving water; number of specimens: I - 1-3, II - 4-10, III 11-32, IV - 33-100, V - 101-316, VI - 317-1000 (based on ALEXANDROWICZ S. W. 1987)

\begin{tabular}{|c|c|c|c|c|c|c|c|c|c|c|c|c|c|c|c|c|c|}
\hline \multirow{2}{*}{$\mathrm{E}$} & \multirow{2}{*}{ TAXON } & \multicolumn{7}{|c|}{ WIGRY LAKE Wg-III } & \multicolumn{3}{|c|}{ Wg-IV } & \multicolumn{6}{|c|}{ BIAŁE LAKE Bi } \\
\hline & & 19 & 20 & 21 & 22 & 23 & 24 & 25 & 26 & 27 & 28 & 1 & 2 & 3 & 4 & 5 & 6 \\
\hline 5 & Vertigo pygmaea & I & & & & & & & & & & & & & & & \\
\hline 5 & Vallonia costata & I & & & & & & & & & & & & & & & \\
\hline 5 & Vallonia pulchella & I & I & I & I & & I & & & & & & & & & & \\
\hline 7 & Cochlicopa lubrica & I & & & I & & & & & II & II & & & & & & \\
\hline 7 & Punctum pygmaeum & I & I & & & & I & I & & & & & & & & & \\
\hline 7 & Nesovitrea hammonis & I & I & & & & & & & & & & & & & & \\
\hline 7 & Euconulus fulvus & I & & & & & & & & & & & & & & & \\
\hline 8 & Carychium tridentatum & & & & & & II & & & & & & & & & & \\
\hline 8 & Vertigo angustior & & I & & & & & & I & I & & & & & & & \\
\hline 8 & Succinea oblonga & & & & & & & & & I & & & & & & & \\
\hline 8 & Nesovitrea petronella & & & & & & I & & I & & & & & & & & \\
\hline 9 & Carychium minimum & I & II & & I & & II & I & II & I & I & & & & & & \\
\hline 9 & Succinea putris & II & I & & II & I & II & & & & II & & & & & & \\
\hline 9 & Zonitoides nitidus & & & & & & I & & I & I & & & & & & & \\
\hline 10 & Valvata pulchella & I & I & II & III & I & & & & & & I & III & II & III & II & IV \\
\hline 10 & Aplexa hypnorum & & & & & & & & & & I & & & & & & \\
\hline 10 & Stagnicola palustris & & II & & & I & & & & & II & & & & & & \\
\hline 10 & Lymnaea truncatula & I & & & & & I & & II & II & III & & & & & & \\
\hline 10 & Lymnaea peregra peregra & & & & & & & & & & & III & & & & & III \\
\hline 10 & Planorbis planorbis & I & & & I & II & III & & IV & IV & $\mathrm{V}$ & & & & & & \\
\hline 10 & Musculium lacustre & & & & & & & & I & I & & & & & & & \\
\hline 10 & Pisidium obtusale & I & II & & & & & & & & & I & & III & & & \\
\hline 11 & Viviparus contectus & I & I & & & & II & I & & & & & & & & & \\
\hline 11 & Valvata cristata & IV & III & $\mathrm{V}$ & IV & $\mathrm{V}$ & IV & II & III & II & II & II & III & III & IV & $\mathrm{V}$ & IV \\
\hline 11 & Valvata piscinalis & II & & II & III & II & I & & & I & I & II & I & II & III & II & III \\
\hline 11 & Potamopyrgus antipodarum & III & I & III & II & II & & & & & & & & & & & \\
\hline 11 & Bithynia tentaculata & III & III & III & IV & III & IV & III & III & III & III & II & II & II & III & IV & IV \\
\hline 11 & Physa fontinalis & & & & & & & I & & & & & & & & & \\
\hline 11 & Lymnaea stagnalis & II & II & & I & & III & III & & & & & & & & & \\
\hline 11 & Lymnaea auricularia & & I & & & & & I & & & & & & & & & \\
\hline 11 & Lymnaea peregra ovata & III & III & III & III & III & III & II & & I & & III & IV & IV & IV & III & IV \\
\hline 11 & Lymnaea peregra ampla & & & III & & & III & & & & & & & & & & I \\
\hline 11 & Planorbarius corneus & I & I & & & I & & & & & & & & & & & \\
\hline 11 & Planorbis carinatus & & & & & & & & & & & & & & & & I \\
\hline 11 & Anisus vorticulus & I & I & III & & I & & & & & & & & & & & \\
\hline 11 & Anisus contortus & I & & III & & I & I & & I & III & I & & & & & & II \\
\hline 11 & Gyraulus albus & II & & & & & III & I & I & II & I & & I & & & & I \\
\hline 11 & Armiger crista & II & I & III & II & II & II & I & II & & & & & & & I & II \\
\hline 11 & Hippeutis complanatus & I & & & & & & & & & & & & & & & \\
\hline 11 & Acroloxus lacustris & & I & & II & & I & I & & & & & & & & & \\
\hline
\end{tabular}




\begin{tabular}{|c|c|c|c|c|c|c|c|c|c|c|c|c|c|c|c|c|c|}
\hline 11 & Sphaerium corneum & I & & & & & II & & & $\mathrm{I}$ & & & & & & & \\
\hline 11 & Pisidium henslowanum & & & & III & & II & & & & & & & & & & \\
\hline 11 & Pisidium milium & & & III & & II & & & & & & I & I & I & I & IV & I \\
\hline 11 & Pisidium subtruncatum & I & II & III & IV & III & IV & II & & I & & I & & & & & I \\
\hline 11 & Pisidium casertanum & IV & III & III & & III & IV & I & & & & III & III & & III & & I \\
\hline 11 & Pisidium crassum & & II & II & III & III & & & & & & I & & & & II & \\
\hline 11 & Pisidium moitessierianum & & & & & & & & & & & & II & & & & \\
\hline 12 & Valvata naticina & I & & & & & & & & & & & & & & & \\
\hline 12 & Anodonta cygnea & I & & & & & & & & & & & & & & & \\
\hline 12 & Pisidium amnicum & & & & & I & III & & & & & & & & I & & \\
\hline 12 & Pisidium nitidum & IV & III & III & III & III & III & I & I & I & & III & III & III & III & IV & IV \\
\hline 12 & Dreissena polymorpha & III & III & IV & III & III & III & & I & I & II & & & & & & \\
\hline
\end{tabular}
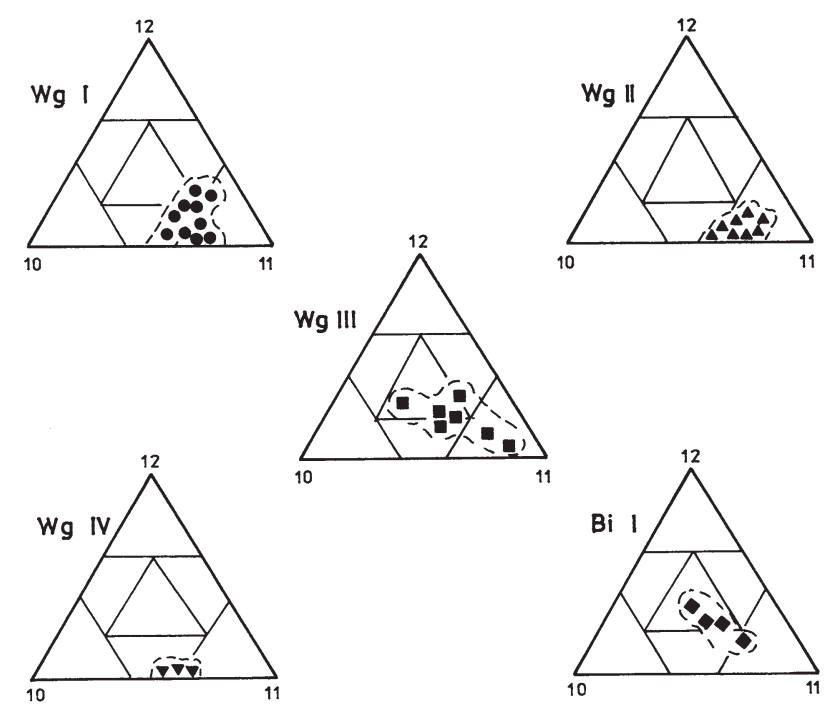

Fig. 3. Triangular diagrams of ecological types of mollusc assemblages

luscs of shallow or even temporary water bodies (Lymnaea truncatula (Müll.) and Planorbis planorbis (L.)) as well as snails and bivalves inhabiting open lakes (Bithynia tentaculata (L.)) are the principal components of the fauna. Land snails (Carychium minimum Müll., Succinea putris (L.)) are accessory components of the assemblage (Fig. 2, Table 2).

Molluscs were found only in one profile (Bi-I) and two single samples (Bi-1, Bi-6) from the lake Białe Wigierskie (Figs. 1, 2; Table 2). The mollusc fauna in profile Bi-I (samples Bi-2 - Bi-5) is relatively poor. It comprises 14 species and 915 specimens (8 and 10 taxa and 122 and 484 specimens per sample). Aquatic molluscs (Bithynia tentaculata (L.), Valvata piscinalis (Müll.), Lymnaea peregra ovata (Drap.), Pisidium milium Held and P. casertanum (Poli)) dominate. The assemblage in question is supplemented by snails typical of shallow water bodies (Valvata cristata Müll., V. pulchella Stud.) as well as a bivalve preferring moving water (Pisidium nitidum Jenyns). Land snails are absent (Fig. 2, Table 2). A similar community occurs in sample $\mathrm{Bi}-1$. Sample $\mathrm{Bi}-6$ derives from a shallow-water zone in the middle part of the lake and comprises a richer fauna (15 species and 531 specimens) (Fig. 2, Table 2). The value of Bithynia-index in the samples from Białe Wigierskie varies between 0.48 and 0.53 which indicates a reed-free zone.

The ecological types of mollusc assemblages are presented in Figure 3. In profiles Wg-I, Wg-II and Wg-IV molluscs typical of big, open lakes prevail, while profiles Wg-III and Bi-I are characterised by a higher proportion of species inhabiting shallow water bodies and taxa preferring moving water.

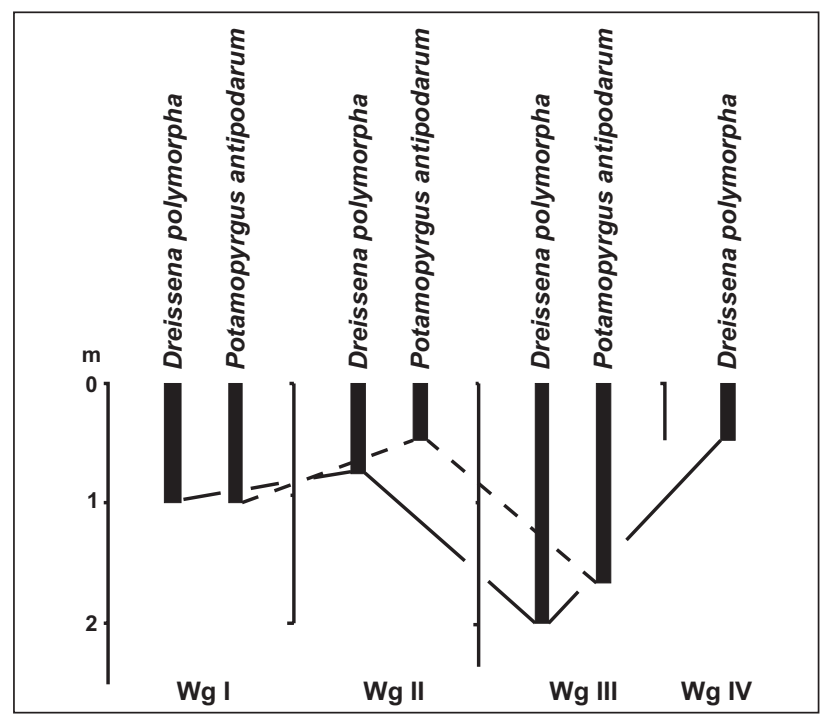

Fig. 4. Distribution of Dreissena polymorpha (Pallas) and Potamopyrgus antipodarum (Gray) in particular profiles from the lake Wigry 


\section{CONCLUSIONS}

The mollusc assemblages from the profiles from the lakes Wigry and Białe Wigierskie are dominated by aquatic molluscs, while terrestrial snails constitute only subordinate components. They occur as single specimens in bore holes Wg-I and Wg-III, situated in the littoral zone of the lake Wigry, as well as in the peat outcrop on the island of Ostrów (Figs 1, 2). They indicate open and humid habitats. Aquatic molluscs, represented mainly by taxa typical of temporary water bodies, lakes and their shallow zones, as well as species associated with slowly moving water, are the principal components of the described fauna. The fauna corresponds to an open, large lake, with a rich vegetation, but devoid of reed. Species found in the bottom calcareous sediments are members of the extant fauna of the mentioned water bodies (POLIŃSKI 1917, 1922, LEWANDOWSKI 1992, KOŁODZIEJCZYK 1994, 1996, BRZEZIŃSKI 1999), however, the number and the density of shells of particular species can be different. Four types of mollusc assemblages can be distinguished:

Assemblage with Valvata (profile Wg-I and lower part of profile Wg-II; Figs 1, 2) is typical of shallow, littoral zones of lakes. Species living on sandy or muddy bottom (Valvata piscinalis (Müll.), V. pulchella Stud., Musculium lacustre (Müll.), Pisidium henslowanum (Shepp.), Sphaerium corneum (L.)), as well as taxa inhabiting submerged plants (Valvata cristata Müll., Bithynia tentaculata (L.), Pisidium milium Held), are the main components of the fauna. The occurrence of bivalves preferring moving water (Pisidium amnicum (Müll.), P. nitidum Jenyns) is the characteristic feature of this assemblage.

Assemblage with Planorbidae and Lymnaeidae (upper part of profile Wg-II, profile Bi-I, samples Bi-1 and Bi-6; Figs 1, 2) is typical of big lakes with rich bottom vegetation. It is composed mainly of numerous specimens of Bithynia tentaculata (L.) and Lymnaea peregra ovata (Drap.). Lymnaea peregra ampla (Hartm.), L. stagnalis (L.), L. auricularia (L.), Armiger crista (L.) and Anisus contortus (L.) are also present. These species are accompanied by some other aquatic snails and bivalves.

Assemblage with admixture of land snails (profile Wg-III; Figs 1, 2) is typical of littoral zone influenced by near-shore processes. The content of shells washed from the island reaches up to $10 \%$ of the community. Water molluscs living both on the bottom and on submerged plants dominate. Bivalves typical of moving water (Pisidium amnicum (Müll.) and P. nitidum Jenyns) are important components of this fauna.

Assemblage associated with marshes (profile Wg-IV; Figs 1, 2) occurs in the peat developed close to the shore of the lake. The fauna is dominated by water molluscs typical of temporary water bodies
(Lymnaea truncatula (Müll.), Planorbis planorbis (L.)). An important admixture of land snails preferring very humid habitats (Succinea putris (L.), Zonitoides nitidus (Müll.)) is noteworthy.

Numerous shells of Dreissena polymorpha (Pallas) and Potamopyrgus antipodarum (Grey) have been found in the upper intervals of profiles $\mathrm{Wg}$-I and $\mathrm{Wg}$-II, as well as in profile Wg-III (Fig. 4, Tables 1, 2). Potamopyrgus antipodarum (Grey) was first noted in Poland in 1933, in the lake Trlacg near Inowrocław (URBAŃSKI 1935). Its occurrence in the lakes Wigry and Białe Wigierskie was observed by LEWANDOWSKI (1992), KOŁODZIEJCZYK $(1994,1996)$ and BRZEZIŃSKI (1999). The main phase of dispersal of Dreissena polymorpha (Pallas) took place within the last 200 years (STAŃCZYKOWSKA 1977, PIECHOCKI \& DYDUCH-FALNIOWSKA 1993). Both species are common in the recent mollusc fauna of Wigry and Białe Wigierskie (LEWANDOWSKI 1992, KOŁODZIEJCZYK 1994, 1996, BRZEZIŃSKI 1999). In profiles Wg-I and Wg-II shells of Potamopyrgus antipodarum (Grey) and Dreissena polymorpha (Pallas) were found at the depth of ca. $0.7 \mathrm{~m}$, while in profile $\mathrm{Wg}$-III they were recorded at $2 \mathrm{~m}$ (Figs 2, 4). The distribution of the mentioned taxa in the bottom sediments reflects the rate of accumulation. The lacustrine chalk with an admixture of sand, distinguished in profile Wg-III, was deposited very fast under the influence of currents, while the calcareous deposits from profiles $\mathrm{Wg}$-I and Wg-II are typical of slow sedimentation in the stagnant water zone.

Calcareous lake deposits, developed as lacustrine chalk or calcareous gyttia, are common in Poland. Most of them are associated with the Late Glacial and Early Holocene. The mentioned sediments contain mollusc assemblages described from numerous localities (BRODNIEWICZ 1979, KRZYMIŃSKA 1987, ALEXANDROWICZ S. W. 1988, 1989, 1991, 1995, ALEXANDROWICZ S. W. \& TCHÓRZEWSKA 1981, ALEXANDROWICZ S. W. \& NOWARCZYK 1982, ALEXANDROWICZ W. P. 1999 and others). At present lacustrine chalk is deposited only in a few lakes. Profiles of of calcareous sediments of the Upper Holocene age, abounding in mollusc shells, described from the lakes Wigry and Białe Wigierskie, can be regarded as a model of deposition and development of lacustrine chalk accumulated in stagnant water and in the part of the lake being still under the influence of currents. These two types of sediments can be recognised based on the differences in their mollusc assemblages and on the presence of species that have dispersed during the last few centuries or even later. These observations can be useful when reconstructing the course of sedimentation and evolution of lake basins. 


\section{ACKNOWLEDGEMENTS}

I am grateful to Prof. dr hab. JACEK RUTKOWSKI and to Ms. KATARZYNA KRÓL, M. Sc. for their help with sampling and processing the material.

\section{REFERENCES}

AleXANDrowicz S. W. 1987. Analiza malakologiczna w badaniach czwartorzędowych. Kwart. AGH Geologia 12: 3-240.

AleXANDROWICZ S. W. 1988. Molluscan assemblages of the lacustrine sediments in the ancient melt-lake Orle. Folia Quaternaria 58: 59-67.

ALEXANDROWICZ S. W. 1989. Zespoły mięczaków w późnoczwartorzędowych osadach jeziornych północnej Polski. Stud. Mat. Ocean. 56: 267-276.

AleXANDrowicz S. W. 1991. The malacofauna of the Holocene lacustrine sediments of Dąbki near Darłowo. Przegl. Archeolog. 38: 19-24.

AleXAndrowicz S. W. 1995. Malacofauna of the Holocene calcareous sediments in Grabowo near Koszalin (Pomerania, North Poland). Quaest. Geogr. 4: 13-20.

AleXANDrowicz S. W., NOWARCZYK B. 1982. Late glacial and Holocene sediments at Pomorsko near Sulechów. Quaest. Geogr. 8: 5-17.

Alexandrowicz S. W., TCHórzewska D. 1981. Kreda jeziorna w osadach czwartorzędowych Środkowego Pomorza. Kwart. AGH Geologia 7: 59-71.

AleXANDrowicz W. P. 1999. Evolution of the malacological assemblages in North Poland during the Late Glacial and Early Holocene. Folia Quaternaria 70: 39-69.

BRODNIEWICZ I. 1979. Analiza faunistyczna późnoglacjalnych osadów słodkowodnych z klifu nadbrzeżnego koło Ustki. Wyd. UAM Geologia 9: 3-27.

BRZEZIŃSKI T. 1999. New localities of Potamopyrgus antipodarum (Gray, 1843) in waters of the Wigry National Park. Folia Malacologica 7: 103-107.

KoŁODZIEJCZYK A. 1994. Mięczaki słodkowodne Suwalskiego Parku Krajobrazowego. In: Jeziora Suwalskiego Parku Krajobrazowego - związki z krajobrazem, stan eutrofizacji, kierunki ochrony (HILLBRICHT-ILKOWSKA S., Wiś-
NIEWSKI R. J., eds). Zesz. Nauk. Kom. "Człowiek i środowisko" PAN 7: 243-265.

KOŁODZIEJCZYK A. 1996. Makrofauna bezkręgowa (ze szczególnym uwzględnieniem Gastropoda) na wybranych makrofitach zanurzonych w litoralu Jeziora Białe Wigierskie. Parki Narodowe i Rezerwaty Przyrody 15: 77-88.

KRZYMIŃSKA J. 1987. Wstępne wyniki badań mięczaków holoceńskich w dolinie rzeki Grabowa koło Koszalina. Spraw. Pos. Kom. PAN 29: 374-375.

LEWANDOWSKI K. 1992. Występowanie i rozmieszczenie mięczaków, ze szczególnym uwzględnieniem małża Dreissena polymorpha (Pall.) w litoralu kilku jezior Wigierskiego Parku Narodowego. In: Stan eutrofizacji i kierunki ochrony (ZDANOWSKI B., ed.): 145-151.

LOŽEK V. 1964. Quartärmollusken der Tschechoslowakei. Rozpr. UUG 31: 3-374.

PIECHOCKI A. 1979. Mięczaki (Mollusca), Ślimaki (Gastropoda). Fauna Słodkowodna Polski 7. PWN, Warszawa.

PIECHOCKI A., DYDUCh-FALNIOWSKA A. 1993. Mięczaki (Mollusca), Małże (Bivalvia). Fauna Słodkowodna Polski 7A. PWN, Warszawa.

POLIŃSKI W. 1917. Materyały do fauny malakozoologicznej Królestwa Polskiego, Litwy i Polesia. Pr. TNW 27: 1-130.

POLIŃSKI W. 1922. O faunie mięczaków Ziemi Suwalskiej. Arch. Hydrob. i Ryb. 1: 37-43.

STAŃCZYKOWSKA A. 1977. Ecology of Dreissena polymorpha (Pall.) (Bivalvia) in lakes. Pol. Arch. Hydrobiol. 24: 461-530.

URBAŃSKI J. 1935. Dwa ciekawe gatunki ślimaków w Wielkopolsce. Wyd. Okr. Kom. Ochr. Przyr. w Poznaniu 5: 108-114.

received: April 4th, 2000

accepted: May 15th, 2000 